\title{
LEAF AREA FOR PHYTOPUMPING OF WASTEWATER
}

\author{
SARWOKO MANGKOEDIHARDJO \\ Laboratory of Environmental Technology and Process Engineering,Department of \\ Environmental Engineering, \\ Institut Teknologi Sepuluh Nopember (ITS) Surabaya, Indonesia \\ (phone: +62-31-594-8886; fax: +62-31-592-8387) \\ e-mail:doctorsarwoko@gmail.com \\ (Received $5^{\text {th }}$ Apr 2006 ; accepted $10^{\text {th }}$ Apr 2007)
}

\begin{abstract}
This report presents novel parameters for evapotranspiration-mediated wastewater phytotreament. Leaf area capacity could be used to measure the water loss from phytotreatment tank. Relative effect concentration was a measure the reduction of leaf area capacity due to increasing COD level. Additional advantage of using the two parameters was to address the suitability of various types of wastewater in phytotreatment by means of COD equivalent.
\end{abstract}

Keywords: evapotranspiration, plant capacity, relative effect

\section{Introduction}

Phytotreatment, aiming to pump wastewater was far behind the progress of improving quality. Investigation on the capacity of plant to treat chemicals has been carried out intensively $[1,2,6,7,8,10,11,12,13,14,16,17]$. However, an upward flow through plant roots, the so called transpiration stream plays an important role aiming to divert wastewater flow into the air. The collective flow of transpiration stream within the plant and evaporation to the air is the so called evapotranspiration. This represents evaporated volume, or weight, of wastewater which detaches from wastewater surface. Therefore the overall treated effluent will be discharged to environmental multimedia, i.e. soil and/or water bodies and air.

The transpiration stream flows at high rate when a plant has its stomates open, normally during the sunny day for the exchange of gases in photosynthesis. Higher transpiration stream is an indication of enhanced chemical uptake by plants [2]. The stream still occurs at a much slower rate through the cellular path [9] when stomates are closed at night, suggesting low chemical uptake. Thus, transpiration stream loading is fluctuated during the day. Moreover, the chemicals-containing transpiration stream may undergo covalent bonding into the lignin of the plant (lignification), and, or transformation to carbon dioxide and water. As a result, a low chemical concentration will detach from the leaf surface. Hence, leaf area capacity should be defined to what extent of the evapotranspiration is partly evaporated from leaves surface. However, the fluctuation of transpiration stream loading may affect the leaf area capacity. In addition, the intensity of the stream may change substantially hydraulic properties of plant tissues and organs, leading to malfunction of leaf for carrying out transpiration. Accordingly, the effect concentration of chemicals should be determined to what extent the leaf area capacity is reduced.

Therefore, the objective of this study was to define leaf area capacity and to assess the effect concentration of chemicals on the leaf area capacity. The inclusion of these 
two parameters in wastewater phytotreatment will increase the suitability of treatment system.

\section{Materials and methods}

Greenhouse experiments were carried out in Pasuruan Industrial Estate at Rembang (PIER), East Java, during the period of July to August 2001 (dry season) and February to March 2002 (rainy season). The experiments were updated in the Laboratory of Environmental Technology and Process Engineering, Institut Teknologi Sepuluh Nopember (ITS), Surabaya, East Java, at the same period in 2003 and 2004.

It was important referring to evapotranspiration of water in order to assess various wastewater characteristics on the flow and leaf area. Moreover, wastewater characteristics could be assessed based on their relative concentration in the water. To this purpose destilate water was used as the control test.

Artificial wastewaters were made of glucose monohydrate (pro analysis) and acetic acid $99.8 \%, 60.5 \mathrm{M}$ (pro analysis) solutions. These were used for reasons that both are highly hidrophilic, hence it should be able to be carried along transpiration stream. The artificial solutions were organized for COD concentration ranging from $20 \mathrm{mg} \mathrm{L}^{-1}$ to $1000 \mathrm{mg} \mathrm{L}^{-1}$. COD measurement was carried out using dichromate method [15]. In addition, collected domestic and industrial wastewaters were tested for this study.

Waterhyacinth was assigned to be the test plant for those solutes for a reason that the plant has a well known capacity to absorb large amounts of water [7, 8]. Hyacinths were collected from a natural watercourse. They were cleaned and placed in nutrient rich water. The plants were placed in nutrient rich water containing Huttner's solution [5] for a week to encourage growth and to ensure that the plants were healthy before placing them in test solutions. After a week of incubation, two propagules of waterhyacinth were selected and placed in the test solution tanks.

The test solution tanks were made of black plastic material of working capacity of 90 1. Each tank had a surface area of $60 \mathrm{sq}-\mathrm{cm}$ and water depth of $30 \mathrm{~cm}$. There were three tanks for each solute, each tanks contained $95 \%$ test solution and $5 \%$ nutrient water to ensure that the availability of nutrients would not be the limiting factor for the growth of the plants. Three replicates were organized simultaneously. Daily observation on temperature, $\mathrm{pH}$, and dissolved oxygen (DO) were measured by means of electronic probes using Water Quality Checker, TOA WQC-22A. The three parameters were useful to confirm growth conditions during the experiment.

Evapotranspiration was measured based on the water loss from the tank. The water loss was measured as the changes of weight for two consecutive period. One period was three days in order to have measurable evaporated weight. The experiment was run for thirty-three days (eleven period) to take plants' acclimatization into account.

Leaf area was measured by means of non-destructive leaf area correction factor. Sixty-four leaf area were drawn in a white paper, having known area (A) and weight (B). Width (W) and length (L) of the drawn leaves were measured. Then the drawn leaf were cut and weighted (C). The leaf area correction factor (cLA) was determined using the following equation:

$$
c L A=\frac{\left(\frac{C}{B}\right) \cdot A}{(W . L)}
$$


Therefore leaf area (LA) measurements for the running experiment were carried out by means of measuring $\mathrm{W}$ and $\mathrm{L}$ and multiplied by cLA using an equation as follows:

$$
L A=c L A \cdot W \cdot L
$$

\section{Results and discussion}

Under the tropical conditions, the solute temperatures for all treatment during exposure were ranging from $25{ }^{\circ} \mathrm{C}$ and $35{ }^{\circ} \mathrm{C}$. Observation on $\mathrm{pH}$ levels in all solutes were shown to decrease from $7.3 \pm 0.1$ to $6.8 \pm 0.1$. Decreasing DO levels from $6.5 \pm$ 0.1 to $4.3 \pm 0.1$ were observed even no mechanical aeration was carried out during the experiment. All the hyacinths were healthy and green during the experiment and most of the plants appeared to grow showing new shoots after a week of exposure. Therefore the solute quality parameters of temperature, $\mathrm{pH}$, and $\mathrm{DO}$ were not limiting conditions for hyacinth growth.

\section{Leaf area capacity}

Results of the cumulative evapotranspiration (ET) in kg water loss from the tank were presented in Table 1. Periodically the values were fluctuated, expressed as CV, due to the prevailing environmental conditions. The fluctuation of ET for a given period was similar characteristic to the fluctuation of drinking water use. One of the purposes of drinking water use fluctuation was to determine reservoir capacity. Accordingly the fluctuation of ET could be treated to calculate the air and plant capacity (APC).

Table 1. Air and plant capacity

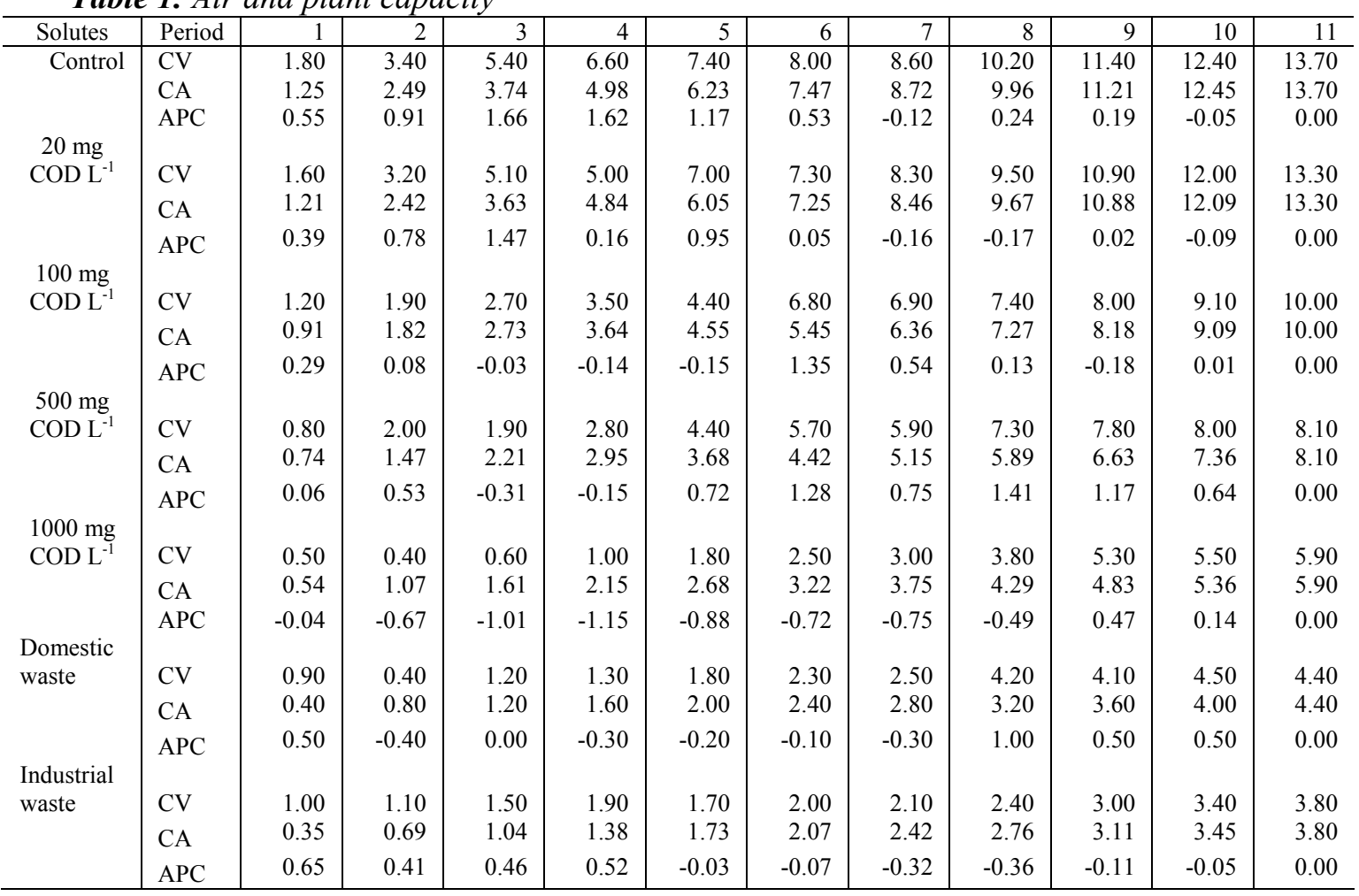

APC was determined as shown in Table 1. The fluctuated CV was substracted by the cumulative average (CA) of ET for a given period. The CA was a constant flow, 
representing balancing flow between $\mathrm{CV}$ and $\mathrm{CA}$. The sum of maximum surplus $(+)$ and maximum deficit (-) was nothing less than APC in $\mathrm{kg}$. The method of this research did not measure the transpiration stream, hence APC consisted of evaporation to the air and upward flow through the plant roots as transpiration stream, each were not known.

In order to assess the plant capacity to conduct transpiration stream, therefore the APC would be correlated to leaf area capacity (LAC) in sq-cm. The LAC was obtained using the same method of calculating APC and presented in Table 2. The significant correlation $\left(\mathrm{R}^{2}=0.9391\right)$ between APC and LAC for COD-containing solutes resulted in the following equation:

$$
L A C=43 A P C-38
$$

Thus each $\mathrm{kg}$ of APC was corresponded to LAC of $5 \mathrm{sq}-\mathrm{cm}$. This LAC was responsible to store transpiration stream. Hence, LAC was nothing less than a reservoir for transpiration stream, regardless the proportion of evaporation and transpiration stream and the fate of the stream in the plant. This result was a proposed parameter of assessing wastewater phytotreatment, aiming to split wastewater flow into environmental multimedia, by means of evapotranspiration measurement.

\section{Relative effect concentration}

Plant can increase the removal of chemical compounds from transpiration stream during uptake, storage, and transpiration; it was the reason why phytotreatment was applied. However, the chemical concentration-containing transpiration stream could have adverse effect on the structure and/or function of the plant. Decreasing LAC due to increasing chemical concentration ranging from $20 \mathrm{mg} \mathrm{L}^{-1}$ and $1000 \mathrm{mg} \mathrm{L}^{-1}$, and introducing wastewaters were representing the adverse effect of chemicals (see Table 2).

Table 2. Leaf area capacity




The relative concentration was used in order to compare the extent of effect for various types of solutes which referred to the control solute. All LACs of chemicalcontaining solute were divided by LAC of control solute. It follows that LACs of chemical-containing solute were lower than 1.0. The relative effect concentration of one $\mathrm{kg} \mathrm{COD} \mathrm{L}{ }^{-1}$ on LAC (RELAC) was formulated in the following equation $\left(\mathrm{R}^{2}=0.8018\right)$ :

$$
R E L A C=0.9 \exp -0.4[C O D]
$$

It follows that increasing COD concentration would bring about decreasing of RELAC. The adverse effect of COD on LAC was considered due to an increase in hydraulic resistance of the cellular plant. This compares favorably with [9] in their work with abscisic acid (ABA).

The RELAC for domestic and industrial wastewaters were 0.7 and 0.6 respectively. It follows that domestic wastewater was equivalent to $300 \mathrm{mg} \mathrm{COD} \mathrm{L}^{-1}$, whereas industrial wastewater was equivalent to $1100 \mathrm{mg} \mathrm{COD} \mathrm{L}^{-1}$. These results were an added value of using the leaf area capacity for predicting the potential evapotranspiration of a known COD-containing wastewater. Hence, RELAC could be used as a measure of various types of wastewater with reference to COD equivalent.

The COD equivalent sources were glucose and acetic acid and indeed any addition from plant exudate such as amino acids, organic acids, fatty acids, sterols, growth factors, nucleotides, flavanones, and enzymes [14]. Benzene, TCE, toluene, ethylbenzene, mxylene, atrazine and aniline were translocated mostly in the leaves [3, 4] that potentially could reduce the leaf area capacity. However, the chemical fate and translocation was most likely concentration-dependent, and other concentrations may give different results. Therefore further investigation is needed for those organic matters to be qualified for COD equivalent.

\section{Conclusions}

Leaf area capacity was expressed as leaf area that brought about by losing weight or volume of soluble organic matter from wastewater tank, regardless the proportion of evaporation and transpiration stream. Five sq-cm of hyacinth leaf area had been able to lose one $\mathrm{kg}$ of COD-containing wastewater in tropical conditions. However, increasing one $\mathrm{kg} \mathrm{COD} \mathrm{L} \mathrm{L}^{-1}$ would result in reducing leaf area capacity of one sq-cm. COD equivalent could be used to measure various types of wastewater for suitability in phytotreatment.

Acknowledgements. The author wishes to thanks Institut Teknologi Sepuluh Nopember (ITS) Surabaya, Universitas Brawijaya Malang and Pasuruan Industrial Estate at Rembang (PIER) under the management of Surabaya Industrial Estate at Rungkut (SIER) for supporting financial and facilities their provided.

\section{REFERENCES}

[1] Bich, N.N., Yaziz, M.I. and Bakti, N.B.K. (1999): Combination of Chlorella vulgaris and Eichhornia crassipes for wastewater N removal. - Water Research, 33(10): 2357-2362.

[2] Briggs, G.G., Bromilow, R.H. and Evans, A.A. (1982): Relationship between lipophilicity and root uptake and translocation of non-ionized chemicals by Barley. - Pesticide Science, 13: 495-504.

[3] Burken, J.G. and Schnoor, J.L.. (1998): Predictive relationships for uptake of organic contaminants by hybrid poplar trees. - Environmental Science \& Technology, 32(21): 3379-3385. 
[4] Burken, J.G. and Schnoor, J.L. (1999): Distribution and volatilization of organic compounds following uptake by hybrid poplars. - International Journal of Phytoremediation, 1(2): 39-151.

[5] Caicedo, J.R., Van Der Steen, O.A. and Gijzen, H.J. (2000): Effect of ammonia N concentration and $\mathrm{pH}$ on growth rates of duckweed. - Water Research, 34(15): 38293835 .

[6] Coleman, J., Hench, K., Garbutt, K., Sexstone, A., Bissonnette, G. and Skousen, J. (2001): Treatment of domestic wastewater by three plant species in constructed wetlands. - Water, Air, and Soil Pollution, 128: 283-295.

[7] Mangkoedihardjo, S. (2002): Waterhyacinth leaves indicate wastewater quality. - Jurnal Biosains, 7(1): 10-13.

[8] Mangkoedihardjo, S. (2006): Biodegradability improvement of industrial wastewater using hyacinth. - J. Applied Sciences, (in press).

[9] Morillon, R. and Chrispeels, M.J. (2001): The role of ABA and the transpiration stream in the regulation of the osmotic water permeability of leaf cells. - Proceedings of the National Academy of Sciences, 98(24): 14138-14143

[10] Newman, L.A., Strand, S.E., Choe, N., Duffy, J., Ekuan, G., Ruszaj, M., Shurtleff, B.B., Wilmoth, J., Heilman, P. and Gordon, M.P. (1997): Uptake and biotransformation of trichloroethylene by hybrid poplars. - Environmental Science \& Technology, 31: 10621067.

[11] Olson, P.E. and Fletcher, J.S. (2000): Ecological recovery of vegetation at a former industrial sludge basin and its implications to phytoremediation. - Environmental Science and Pollution Research, 7: 1-10.

[12] Salt, D.E., Blaylock, M., Nanda Kumar, P.B.A., Dushenkov, V., Ensley, B.D., Chet, I. and Raskin, I. (1995): Phytoremediation: A novel strategy for the removal of toxic metals from the environment using plants. - Biotechnology, 13: 468-474.

[13] Schnoor J.L., Light, L.A., McCutcheon, S.C., Wolfe, N.L. and Carriera, L.H. (1995): Phytoremediation of Organic and Nutrient Chemicals. - Environmental Science \& Technology, 29: 318-323.

[14] Shimp, J.F., Tracy, J.C., Davis, L.C., Lee, E., Huang, W., Erickson, L.E. and Schnoor, J.L. (1993): Beneficial effects of plants in the remediation of soil and groundwater contaminated with organic materials. - Critical Review in Environmental Science and Technology, 23: 41-77.

[15] Standard Methods. (1995): Standard Methods for the Examination of Water and Wastewater. - American Public Health Association/American Water Works Association/Water Environmental Federation, Washington DC, 19th Edition.

[16] Toft, D., Simenstad, C. and Cordell, J. (2003): The effects of introduced water hyacinth on habitat structure, invertebrate assemblages, and fish diets. - Estuaries, 26: 746-758.

[17] Yirong, C. and Puetpaiboon, U. (2004): Performance of constructed wetland treating wastewater from seafood industry. - Water Science \& Technology, 49(5-6): 289 - 294. 